\title{
5-Fluorouracil/leucovorin-induced inhibition of thymidylate synthase in normal tissues of mouse and man
}

Received: 9 April 1997 / Accepted: 27 July 1997

\begin{abstract}
We evaluated the effects of 5-fluorouracil (5FU) and leucovorin (LV) on thymidylate synthase (TS) in normal rapidly dividing tissues, which may contribute to toxic side-effects of treatment with 5FU and LV. TS levels were determined in biopsies of human liver and colon mucosa and murine bone marrow, liver and intestinal mucosa at several time points after administration of therapeutic doses of $5 \mathrm{FU}$ or $\mathrm{LV} / 5 \mathrm{FU}$. In murine liver, after treatment with $100 \mathrm{mg} / \mathrm{kg} 5 \mathrm{FU}$, TS inhibition was significantly higher than after LV/5FU administration $(P<0.001)$. A similar trend was observed in human liver tissue. Murine intestinal mucosa had TS levels below the limit of detection after $5 \mathrm{FU}$ or $\mathrm{LV} / 5 \mathrm{FU}$ treatment. In human colon mucosa samples, administration of $500 \mathrm{mg} / \mathrm{m}^{2} 5 \mathrm{FU}$ resulted in a large extent of TS inhibition but the small number of samples did not allow a time- or 5FU-LV/5FU-related evaluation. TS activity in murine bone marrow cells was strongly inhibited to $10 \%$ of the control value during $48 \mathrm{~h}$. LV/ 5FU administration resulted in a slightly higher inhibition. No human bone marrow was available to measure TS levels. Both in mice and humans the most pronounced TS inhibition occurred in the tissue that was involved in dose-limiting toxicity. Therefore it is very likely that TS inhibition in normal tissues contributes to the toxic side-effects of 5FU treatment.
\end{abstract}

Key words 5-Fluorouracil · Leucovorin · Thymidylate synthase $\cdot$ Colon cancer

C.L. van der Wilt · C.J. van Groeningen - H.M. Pinedo

K. Smid · K. Hoekman · G.J. Peters ( $₫)$

Department of Medical Oncology,

University Hospital Vrije Universiteit,

Postbox 7057, 1007 MB Amsterdam, The Netherlands

Tel.: + 31204442633

Fax: + 31204443844

e-mail: gj.peters@azvu.nl

S. Meijer

Department of Surgery, Academic Hospital Vrije Universiteit,

Amsterdam, The Netherlands

\section{Introduction}

Combination chemotherapy of 5-fluorouracil (5FU) and leucovorin (LV) is mainly used for the treatment of colon cancer, but has also been applied for breast and head and neck cancer (Peters and van Groeningen 1991). In this combination $5 \mathrm{FU}$ is the active cytotoxic agent. The 5FU nucleotides 5-fluorouridine 5'-triphosphate (FUTP) and 5-fluoro-2'-deoxyuridine 5'-triphosphate (FdUTP) can be misincorporated into RNA and DNA respectively. A third metabolite, 5-fluoro-2'-deoxyuridine $5^{\prime}$-monophosphate (FdUMP) is a potent inhibitor of the enzyme thymidylate synthase (TS, EC 2.1.1.45; 5,10-methylenetetrahydrofolate:dUMP $C$-methyltransferase), an essential enzyme in the synthesis of DNA. The inhibition of TS by FdUMP can be enhanced and prolonged by the LV metabolite 5,10-methylenetetrahydrofolate $\left(5,10-\mathrm{CH}_{2}-\mathrm{H}_{4}\right.$-folate). A stable ternary complex is formed consisting of TS, FdUMP and $\mathrm{CH}_{2-}$ $\mathrm{H}_{4}$-folate (Danenberg 1977). This biochemical effect forms the background for the coadministration of $\mathrm{LV}$ with 5FU. Naturally occurring low $5,10-\mathrm{CH}_{2}-\mathrm{H}_{4}$-folate levels in tissues, which are limiting for inhibition of TS, can be elevated by LV administration. Administration of $\mathrm{LV} / 5 \mathrm{FU}$ to patients has been shown to result in a better inhibition of TS than that produced by $5 \mathrm{FU}$ alone (Swain et al. 1989; Peters et al. 1994). The increased TS inhibition observed after $\mathrm{LV} / 5 \mathrm{FU}$ resulted in a better antitumour effect, compared to the effects of singleagent 5FU (Swain et al. 1989). These observations reflect the importance of TS inhibition in tumours with regard to antiproliferative effects.

The most frequently seen dose-limiting toxic sideeffects of 5FU are myleosuppression after bolus injections and gastrointestinal toxicity after continuous infusion of 5FU (Peters and van Groeningen 1991; Leichman 1994). Coadministration of LV and 5FU did not only improve the antitumour activity of $5 \mathrm{FU}$, as has been shown in both murine and human colon tumours, but also increased the gastrointestinal toxicity compared with bo- 
lus 5FU treatment in both species (Nadal et al. 1988; Piedbois et al. 1992). It has not been completely elucidated which of the biochemical mechanisms of action of $5 \mathrm{FU}$ is involved in toxic side-effects in normal tissues. For gastrointestinal mucosa, incorporation into the RNA was postulated to be an important mechanism in mice (Houghton et al. 1979; Martin et al. 1982), but not much has been written about the mechanism for bone marrow cells and liver tissue. It has been shown that delayed uridine administration reduces myeloid toxicity (Nadal et al. 1989; van Groeningen et al. 1989, 1993). This observation indicates the type of RNA effects that are related to toxicity, since uridine reduced 5FU incorporation into RNA, but did not affect TS inhibition (Peters et al. 1988; Nord et al. 1992).

Little is known about TS activity and 5FU-induced TS inhibition in normal human tissues. One may speculate that TS levels are relatively high in rapidly dividing and DNA-synthesising tissues, such as the gastrointestinal mucosa and bone marrow. Is TS inhibited in these tissues after 5FU administration? Furthermore is there a relation between TS inhibition and the toxic side-effects of 5FU administration that occur in these tissues?

We studied the effect of i.p. 5FU administration on the inhibition of TS in normal murine bone marrow, intestinal mucosa and liver tissues. The murine liver tissue was included in this study because of the comparison with human liver that could be obtained from patients with liver metastases of colon cancer. A study of Harrison et al. (1978) has shown that toxicity due to $5 \mathrm{FU}$ in mice is highly similar to that in humans. The effects of coadministration of LV with 5FU on TS were primarily studied in mice. We compared the preclinical results with TS inhibition measured in liver and normal colon mucosa of patients, who had received a bolus injection of $5 \mathrm{FU}$ or $\mathrm{LV}$ infusion with a midway bolus injection of 5FU before surgery. The present study, performed in normal tissues of mice and humans, provides an insight into the contribution of TS inhibition to the toxic side-effects of $5 \mathrm{FU}$.

\section{Materials and methods}

\section{Materials}

5FU was obtained from ABIC (Netanya, Israel) and LV was provided by Wyett-Lederle (Amsterdam, The Netherlands) and the pharmacy department of the Free University Hospital (Amsterdam, the Netherlands). $\left[6-{ }^{3} \mathrm{H}\right]$ FdUMP (specific activity $20 \mathrm{Ci} /$ $\mathrm{mmol}$ ) was purchased from Moravek Biochemicals Inc. (Brea, Calif., USA) and $\left[5-{ }^{3} \mathrm{H}\right] \mathrm{dUMP}$ (specific activity $10.9 \mathrm{Ci} / \mathrm{mmol}$ ) from Amersham International (Buckinghamshire, England). All other chemicals were of analytical grade, and were commercially available.

\section{Mice}

Female Balb/c mice (age 8-10 weeks, about 20 g) (Harlan/Olac; C.P.B., Zeist, The Netherlands) received a single i.p. bolus injection of $100 \mathrm{mg} / \mathrm{kg} 5 \mathrm{FU}$. This is the maximal tolerated dose for weekly i.p. injections (Peters et al. 1987). LV was given as an i.p. bolus injection $1 \mathrm{~h}$ before and together with $5 \mathrm{FU}$ in two doses of $50 \mathrm{mg} /$ $\mathrm{kg}$ (total dose $\mathrm{LV} 100 \mathrm{mg} / \mathrm{kg}$ ). This schedule was derived from the experiments of Nadal et al. (1988). At this dose the weight loss of mice amounted to $5 \%-15 \%$ as a result of gastrointestinal toxicity, while blood cells decreased to $40 \%$. No liver toxicity was apparent. Delivery by i.p. bolus in small animals such as rats and mice results in pharmacokinetic behaviour similar to that following systemic i.v. bolus treatment in man (De Bruijn et al. 1986; Peters et al. 1993), such as a comparable half-life of 10-15 min.

Liver tissue, intestinal mucosa and bone marrow cells of the mice were removed 3, 24 and $48 \mathrm{~h}$ after treatment and immediately frozen in liquid nitrogen. Samples from untreated mice served as controls.

\section{Patients}

Patients in this study (Table 1) all underwent surgery for therapeutic purposes, i.e. implantation of a Port-a-Cath to be used for subsequent hepatic arterial infusions with 5FU. Informed consent was obtained from all patients before surgery and drug administration. Control liver samples were obtained from 8 patients with a known malignant disease, namely colon cancer without liver metastases. 5FU or LV/5FU samples (colon and/or liver tissue) were from patients who all had histologically proven colorectal cancer. These patients (36) received a single dose of $5 \mathrm{FU}$ at $500 \mathrm{mg} / \mathrm{m}^{2}$ or (29 patients) were given LV administered as a 2-h infusion, with a bolus injection of $5 \mathrm{FU}$ at $500 \mathrm{mg} / \mathrm{m}^{2}$ in the middle of the infusion. Three doses of LV were used: $25 \mathrm{mg} / \mathrm{m}^{2}$ or $500 \mathrm{mg} / \mathrm{m}^{2}$ racemic DL$\mathrm{LV}$ or $250 \mathrm{mg} / \mathrm{m}^{2}$ purified L-LV, which is believed to be the more active of the stereoisomers. These chemotherapeutic agents were given as a single test dose before surgery in order to examine inhibition of TS in surgical samples. Biopsy specimens were taken between $1 \mathrm{~h}$ and $48 \mathrm{~h}$ after treatment and immediately frozen in liquid nitrogen.

Thymidylate synthase assays on tissues

TS inhibition was evaluated with two assays, which provided different information. The ligand-binding assay gives an estimate of the amount of (free) TS protein. The assay with $\left[6-{ }^{3} \mathrm{H}\right] \mathrm{FdUMP}$ determined the free binding sites for FdUMP. Tissue homogenate was incubated with $\left[6-{ }^{3} \mathrm{H}\right] \mathrm{FdUMP}$ and the cofactor $5,10-\mathrm{CH}_{2}-\mathrm{H}_{4}$ folate at $37^{\circ} \mathrm{C}$. After $1 \mathrm{~h}$, free $\left[6{ }^{3} \mathrm{H}\right] \mathrm{FdUMP}$ was removed by a charcoal wash and $\left[6-{ }^{3} \mathrm{H}\right] \mathrm{FdUMP}$ bound to TS was counted. The other assay, the ${ }^{3} \mathrm{H}$-release assay, gives information about the catalytic activity of the enzyme. One binding site, as measured in the ligand-binding assay, can serve for one or more catalytic conversions. We used $\left[5-{ }^{3} \mathrm{H}\right] \mathrm{dUMP}$ to measured the catalytic activity of the enzyme in converting dUMP into dTMP. Two substrate

Table 1 Data on patient characteristics and sample numbers. The number of patients in each drug administration group and the number of tissue samples obtained from the whole patient group are summarized. $5 F U$ 5-fluorouracil, $L V$ leucovorin. Subscripts (DL- $\mathrm{LV}_{25}$ etc.) indicate the doses used $\left(\mathrm{mg} / \mathrm{m}^{2}\right)$

\begin{tabular}{|c|c|}
\hline Number (male/female) & $73(37 / 36)$ \\
\hline Median age (years) & $55(34-78)$ \\
\hline Control & 8 patients \\
\hline $5 \mathrm{FU}$ & 36 patients \\
\hline $\mathrm{LV} / 5 \mathrm{FU}\left(\mathrm{DL}-\mathrm{LV}_{25} ; \mathrm{DL}-\mathrm{LV}_{500} ; \mathrm{L}-\mathrm{LV}_{250}\right)$ & $29(11 ; 10 ; 8)$ patients \\
\hline Colon mucosa only & 5 patients \\
\hline Liver only & 57 patients \\
\hline Colon mucosa and liver & 11 patients \\
\hline Total colon mucosa & 16 samples \\
\hline Total liver & 68 samples \\
\hline
\end{tabular}


concentrations of dUMP were used in the catalytic activity assay: $1 \mu \mathrm{M}$, which is around the $K_{\mathrm{m}}$, and $10 \mu \mathrm{M}$, a saturating substrate concentration. Tissue homogenate was incubated with $\left[5-{ }^{3} \mathrm{H}\right] \mathrm{dUMP}$ and the cofactor $5,10-\mathrm{CH}_{2}-\mathrm{H}_{4}$-folate at $37^{\circ} \mathrm{C}$. After $30 \mathrm{~min}$ $\left[5-{ }^{3} \mathrm{H}\right] \mathrm{dUMP}$ bound to TS and free $\left[5-{ }^{3} \mathrm{H}\right] \mathrm{dUMP}$ were precipitated by an acid charcoal wash. The amount of $\left[{ }^{3} \mathrm{H}\right] \mathrm{H}_{2} \mathrm{O}$ released during the reaction was measured in the supernatant. Details of the assays have been published elsewhere (van der Wilt et al. 1992; Peters et al. 1991, 1994).

The control values of murine tissues were determined by measuring TS in samples of untreated mice. The Balb/c mice that we used are an inbred strain and genetically nearly identical, so variations in TS are small.

We used two methods to determine control values in the human tissues. First, controls for the patient's material were obtained by a dissociation procedure performed on a part of each $5 \mathrm{FU}$ or $\mathrm{LV} /$ $5 \mathrm{FU}$ sample, since it was not possible to receive control tissue from the same patient before 5FU injection. The dissociation procedure removed all FdUMP bound to TS in the presence of a high concentration dUMP. The free FdUMP was absorbed with neutral charcoal. Details of the procedure have been described previously (van der Wilt et al. 1992). Second, we obtained control liver samples from untreated patients. These samples underwent the same procedure as the $5 \mathrm{FU}$ and $\mathrm{LV} / 5 \mathrm{FU}$ samples: one part was used for the dissociation procedure followed by TS assays, the other part was used for direct measurement of TS. This allowed us to check the effects of the dissociation procedure in liver samples. FdUMP binding measured after dissociation is referred to as TS-tot, while directly measured FdUMP binding is called TS-free. Analogous TS activity measured after dissociation is called TS-total and directly measured activity is referred to as residual TS activity. Furthermore, we examined whether addition of $0.01 \mu \mathrm{M}$ FdUMP in the catalytic activity assay would lead to the same extent of TS inhibition in directly measured samples and samples measured after dissociation. The colon mucosa samples obtained from patients treated with $5 \mathrm{FU}$ or $\mathrm{LV} / 5 \mathrm{FU}$ were handled like the liver samples. Control values for colon mucosa of untreated patients were derived from previously published experiments (Peters et al. 1991).

We also attempted to measure TS levels in human lymphocytes as an indication of bone marrow TS. Up to $9 \times 10^{7}$ cells were collected from healthy volunteers, but even with this high number of cells per assay, TS levels were below the detection limit.

\section{Statistics}

The results were evaluated using Student's $t$-test for paired and unpaired data.

\section{Results}

\section{Mice}

The i.p. 5FU or LV/5FU treatment affected TS in normal tissues of the mice. TS inhibition in murine liver was evaluated both with the ligand-binding assay and the catalytic activity assay and is summarized in Table 2. Both assays showed that the LV/5FU treatment caused no inhibition of TS in the liver, while treatment with $5 \mathrm{FU}$ as a single agent caused a significant inhibition of TS activity at $24 \mathrm{~h}$ and $48 \mathrm{~h}$. The ratio calculated from separate values for catalytic activity, measured at $1 \mu \mathrm{M}$ and $10 \mu \mathrm{M}$ dUMP, was $2.0 \pm 0.03$ for the control and is indicative of a difference in the enzyme kinetic properties. A significant decrease of this ratio was observed $48 \mathrm{~h}$ after $5 \mathrm{FU}$ treatment $(1.7 \pm 0.1, P<0.001)$, while the ratio increased significantly after $\mathrm{LV} / 5 \mathrm{FU}$ administration $(2.2 \pm 0.1, P<0.05)$. LV $/ 5 \mathrm{FU}$ had a slight inhibitory effect at $1 \mu \mathrm{M}$ dUMP, while single-agent $5 \mathrm{FU}$ exerted its major effect at $10 \mu \mathrm{M}$. This could be, for example, a change in $K_{\mathrm{i}}$ for FdUMP, which was $0.5 \mathrm{nM}$ in control liver.

The control values for TS in intestinal mucosa were about 1.5-fold higher than in liver (6.6 compared to $4.3 \mathrm{pmol} / \mathrm{g}$ wet weight for FdUMP binding and 130 compared to $80 \mathrm{pmol} \mathrm{h}^{-1} \mathrm{mg}$ protein ${ }^{-1}$ for catalytic activity respectively). After treatment, no activity of TS could be observed in mucosa; all values at 3,24 and $48 \mathrm{~h}$ were below the detection limit of both TS assays. FdUMP binding lower than $4 \mathrm{fmol} / \mathrm{mg}$ protein and catalytic activity lower than $10 \mathrm{pmol} \mathrm{h}^{-1} \mathrm{mg}_{\text {protein }}^{-1}$ could not be measured reliably in murine mucosa.

FdUMP binding in bone marrow could be measured in pooled control samples and was $1471 \pm 293 \mathrm{fmol} / \mathrm{mg}$ protein; the catalytic activity of TS at $1 \mu \mathrm{M}$ and $10 \mu \mathrm{M}$ was $1081 \mathrm{pmol} \mathrm{h}^{-1} \mathrm{mg}_{\text {protein }}^{-1}$ and $4622 \mathrm{pmol} \mathrm{h}^{-1} \mathrm{mg}$ protein $^{-1}$ respectively. After treatment, TS inhibition was only evaluable with the ${ }^{3} \mathrm{H}$-release assay at $1 \mu \mathrm{M}$ dUMP (Fig. 1). This assay allowed the detection of a high degree of TS inhibition (above 90\%) at $3 \mathrm{~h}$ and $48 \mathrm{~h}$. LV/5FU treatment resulted in a slightly higher

Table 2 FdUMP binding and thymidylate synthase $(T S)$ catalytic activity in murine liver. This was measured at three time points after treatment of the mice with $5 \mathrm{FU}(100 \mathrm{mg} / \mathrm{kg})$ or $\mathrm{LV}(100 \mathrm{mg} / \mathrm{kg})$ and $5 \mathrm{FU}$ and compared to control murine liver tissue. Values are means $\pm \mathrm{SD}, n=3-6$; protein content of liver: $99 \pm 14 \mathrm{mg}$ protein $/ \mathrm{g}$ wet weight

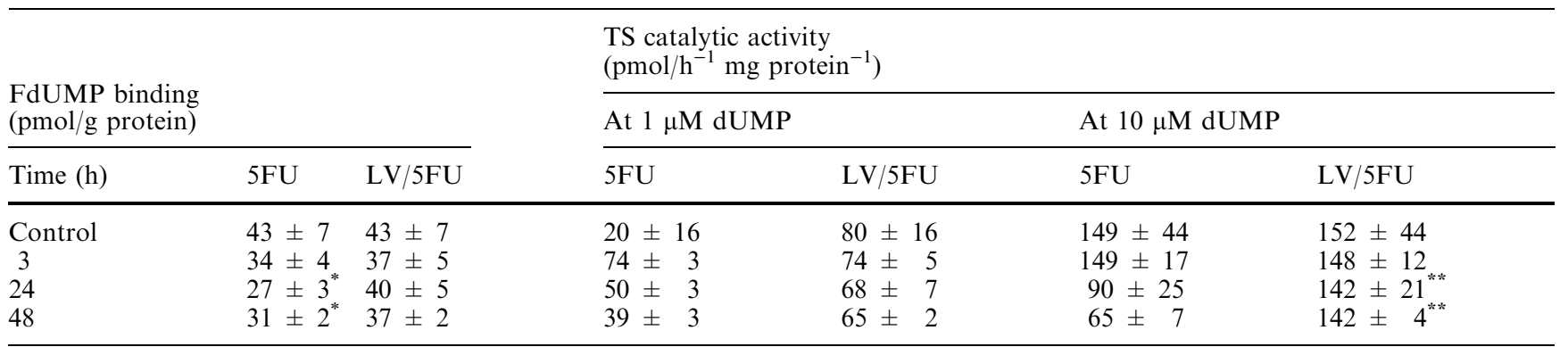

\footnotetext{
${ }^{*}$ Significantly different from control $(P<0.05$, Student's $t$-test unpaired data)

:*: Significantly different from 5FU treatment $24 \mathrm{~h}(P<0.02)$ and $48 \mathrm{~h}(P<0.001$, Student's $t$-test unpaired data)
} 


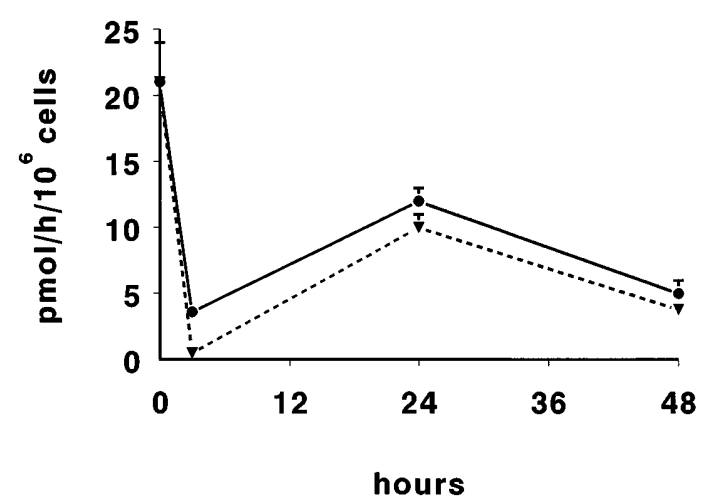

Fig. 1 Comparison of residual thymidylate synthase catalytic activity (at $1 \mu \mathrm{M}$ dUMP) after i.p. treatment with $100 \mathrm{mg} / \mathrm{kg} 5$-fluorouracil $(5 \mathrm{FU} ; \boldsymbol{O})$ or $100 \mathrm{mg} / \mathrm{kg}$ leucovorin and $100 \mathrm{mg} / \mathrm{kg} 5 \mathrm{FU}(\boldsymbol{\nabla})$ in murine bone marrow cells. Values are means $\pm \mathrm{SD}, n=3-5$, protein content about $18 \mu \mathrm{g}$ protein $/ 10^{6}$ cells

inhibition of TS activity at the different assay times than did 5FU treatment, but differences were only significant at $3 \mathrm{~h}(P<0.001)$. The unexpected higher activity of TS at $24 \mathrm{~h}$, compared to $48 \mathrm{~h}$, was found for both treatments.

\section{Patients}

The dissociation procedure was intended to provide an internal control for all liver samples obtained after $5 \mathrm{FU}$ or LV/5FU administration. However, the TS catalytic activity measured after dissociation (TS-total) was lower than the residual TS activity in 31 of 53 liver samples. This indicated a loss of TS activity during the 3-h dissociation procedure. Control human liver samples were subsequently used to examine the effects of the dissociation procedure. FdUMP binding measured in control samples from untreated patients was not influenced by the dissociation procedure; values were about $70 \mathrm{pmol} /$ mg protein (Table 3). However, these values are much higher than the TS-tot measured after $5 \mathrm{FU}$ and $\mathrm{LV} /$ 5FU: $15.3 \mathrm{pmol} / \mathrm{mg}$ protein (Table 4). This indicated that 5FU with or without LV influenced TS-tot levels in the liver. TS catalytic activity, measured directly or after dissociation, showed that the dissociation procedure clearly diminished the activity of TS and also the $K_{\mathrm{i}}$ of FdUMP seemed to be affected (Table 3).

We could evaluate FdUMP binding in 47 of 60 liver samples obtained after $5 \mathrm{FU}$ or $\mathrm{LV} / 5 \mathrm{FU}$ administration. TS-free values were lower than TS-tot values $2 \mathrm{~h}$ and $48 \mathrm{~h}$ after $5 \mathrm{FU}$ or $\mathrm{LV} / 5 \mathrm{FU}$, indicating inhibition of TS, but TS-free was comparable to TS-tot $24 \mathrm{~h}$ after $5 \mathrm{FU}$.

Table 3 FdUMP binding and thymidylate synthase catalytic activity in control liver of patients. The values are means \pm SD of $6-8$ samples. $K_{\mathrm{i}}$ values were calculated from each separate sample

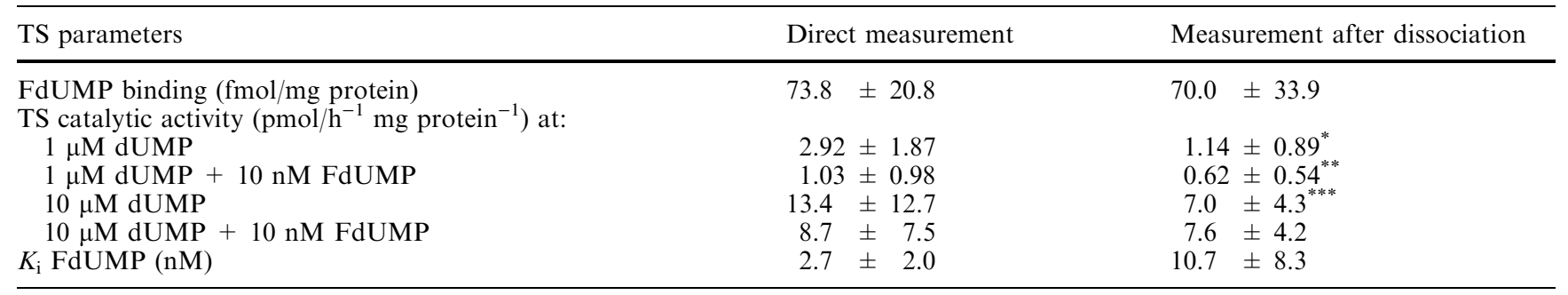

${ }^{*-* * *}$ Values significantly lower after dissociation $\left({ }^{*} P=0.029,{ }^{* *} P=0.010\right.$ and ${ }^{* * *} P=0.048, t$-test for paired data)

Table 4 FdUMP binding to thymidylate synthase $(T S)$ in human liver after $5 \mathrm{FU}$ or $\mathrm{LV} / 5 \mathrm{FU}$ administration. The values of TS-free and TS-tot are means of evaluable samples \pm SD. FdUMP binding to TS-tot of 12 patients was below the detection limit and for 2 patients TS-tot was extremely high ( 88 and $1071 \mathrm{fmol} / \mathrm{mg}$ protein); these were considered not evaluable and were not included in this table. Protein content liver: $96 \pm 21 \mathrm{mg}$ protein/g wet weight. $e / n$ number of evaluable samples compared to the total number of samples

\begin{tabular}{|c|c|c|c|c|c|}
\hline \multicolumn{2}{|l|}{ Time $(\mathrm{h})$} & \multirow[b]{2}{*}{ Drug } & \multirow[b]{2}{*}{$e / n$} & \multicolumn{2}{|c|}{ Thymidylate synthase (fmol/mg protein) } \\
\hline Scheduled & Actual & & & TS-free & TS-tot \\
\hline $\begin{array}{l}\text { Control } \\
2 \\
24 \\
48 \\
48\end{array}$ & $\begin{array}{c}1.25-5.08 \\
19.00-26.25 \\
41.75-67.50 \\
39.00-51.00 \\
40.08-48.80 \\
39.00-51.00 \\
41.30-50.00\end{array}$ & 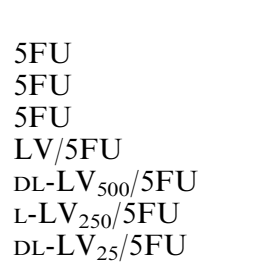 & $\begin{array}{c}8 / 8 \\
3 / 8 \\
7 / 9 \\
12 / 16 \\
25 / 27 \\
6 / 8 \\
8 / 8 \\
11 / 11\end{array}$ & $\begin{aligned} 7.1 & \pm 6.8^{* 1} \\
18.8 & \pm 18.6 \\
8.7 & \pm 7.1^{* 2} \\
11.3 & \pm 5.8^{* 3} \\
13.6 & \pm 3.9 \\
13.4 & \pm 6.7 \\
8.5 & \pm 5.3\end{aligned}$ & $\begin{array}{rr}73.8 \pm & 20.8 \\
17.7 \pm & 3.9 \\
19.4 \pm & 14.6 \\
15.9 \pm & 11.0 \\
14.0 \pm & 9.2 \\
16.1 \pm & 6.7 \\
17.3 \pm & 9.6 \\
10.6 \pm & 9.6\end{array}$ \\
\hline Summary & $1.25-50.00$ & $5 \mathrm{FU}$ and $\mathrm{LV} / 5 \mathrm{FU}$ & $47 / 60$ & $11.5 \pm 9.4$ & $15.3 \pm 10.3^{* 4}$ \\
\hline
\end{tabular}

${ }^{* 1-* 4}$ Statistics: TS-free is lower than TS-tot: ${ }^{* 1} P=0.04 ;{ }^{* 2} P=0.05 ;{ }^{* 3} P=0.02$, paired $t$-test. TS-tot of $5 \mathrm{FU}$ and LV $/ 5 \mathrm{FU}$ samples is lower than TS-tot of control $\left({ }^{*} P=2 \times 10^{-5}\right.$, unpaired $t$-test) 


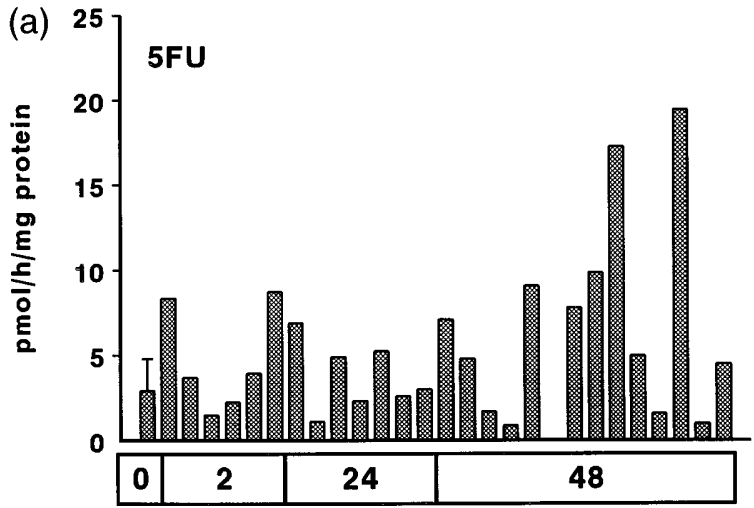

Fig. 2a, b Residual thymidylate synthase (TS) catalytic activity at $1 \mu \mathrm{M}$ dUMP in biopsy specimens of human liver. Patients received a single dose of $500 \mathrm{mg} / \mathrm{m}^{2} 5 \mathrm{FU}$ (a) or $500 \mathrm{mg} / \mathrm{m}^{2}$ DL-leucovorin $(d, l-L V)$, $250 \mathrm{mg} / \mathrm{m}^{2}$ L-leucovorin $(l-L V)$ or $25 \mathrm{mg} / \mathrm{m}^{2}$ DL-leucovorin in combination with $500 \mathrm{mg} / \mathrm{m}^{2}$ 5FU (b). Biopsy specimens were obtained at the times indicated at the bottom of the figure. For time $0 \mathrm{~h}$, the control value from Table 4 has been used. Statistics: residual TS activity $48 \mathrm{~h}$ after drug administration is significantly higher than the control $(P=0.05)$; specified per drug: 5FU 48, $P=0.12 ; 500 \mathrm{mg}$ / $\mathrm{m}^{2}$ DL-leucovorin $+5 \mathrm{FU}, \quad P=0.013 ; 250 \mathrm{mg} / \mathrm{m}^{2}$ L-leucovorin $+5 \mathrm{FU}, P=0.054 ; 25 \mathrm{mg} / \mathrm{m}^{2}$ DL-leucovorin $+5 \mathrm{FU}, P=0.11$

When measured after $48 \mathrm{~h}, 5 \mathrm{FU}$ samples had TS-free values that were comparable to those of LV/5FU samples and also their relative inhibition, calculated by TSfree/TS-tot, was comparable. So LV did not enhance $5 \mathrm{FU}$-induced TS inhibition in liver tissue.

Figure $2 \mathrm{a}$ shows the residual TS catalytic activity in liver samples at about 2, 24 and $48 \mathrm{~h}$ after 5FU injection. Figure $2 \mathrm{~b}$ shows a comparison of the activity at $48 \mathrm{~h}$ after injection of $5 \mathrm{FU}\left(500 \mathrm{mg} / \mathrm{m}^{2}\right)$ and infusion of different doses of LV. We considered inhibition of TS activity based on the ratio TS-residual/TS-total not evaluable in these samples, because it is probable that, as in control samples, dissociation reduced the TS-total activity (not shown) by about $50 \%$. Therefore we used the directly measured activity of Table 3 as a reference TS-total; TSresidual $48 \mathrm{~h}$ after $5 \mathrm{FU}$ and $\mathrm{LV} / 5 \mathrm{FU}$ injection was higher than this control, mainly because of the values of DL-

Table 5 FdUMP binding to thymidylate synthase $(T S)$ in human colon mucosa after $5 \mathrm{FU}$ or $\mathrm{LV} / 5 \mathrm{FU}$ administration. The values of TS-free and TS-tot are means of evaluable samples \pm SD. FdUMP binding to TS-tot of 4 patients (excluding controls) was below the

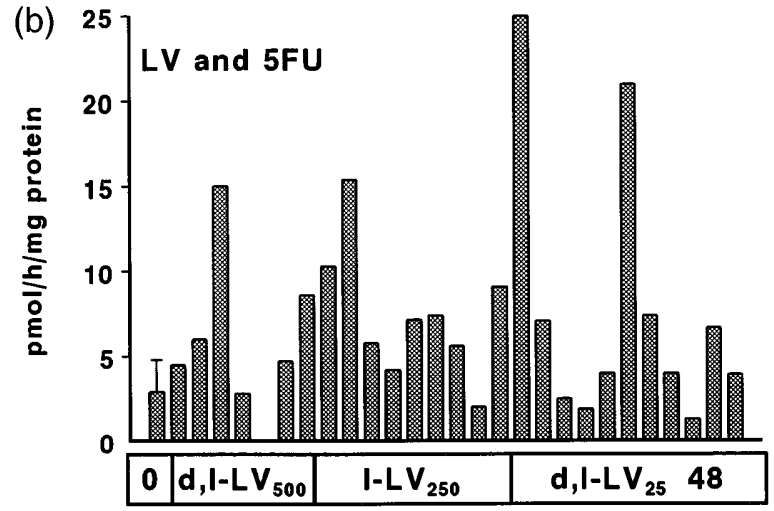

$\mathrm{LV}_{500}$ and $\mathrm{L}-\mathrm{LV}_{250}$. At the other assay times TS-residual was not significantly different from the control.

The enzyme assays in colon mucosa were not perturbed by the dissociation procedure. The total FdUMP binding to TS (TS-tot) in human colon mucosa could only be evaluated in 12 of the 17 biopsies (excluding controls) and varied in these samples from 11.3 to $192 \mathrm{fmol} / \mathrm{mg}$ protein (Table 5). These TS-tot values did not differ significantly from the controls, and both groups showed a large variation. The remaining 4 samples had FdUMP binding below the detection limit of the assay. The number of free sites for FdUMP binding to TS after administration of $5 \mathrm{FU}$ or $\mathrm{LV} / 5 \mathrm{FU}$, represented by TS-free, were all lower than the corresponding TS-tot values. This indicated that FdUMP binding sites were blocked and TS was inhibited in colon mucosa.

TS catalytic activity (Fig. 3) could be evaluated in 15 of the 16 mucosa samples (excluding controls) of treated patients. The TS-total value of these samples was significantly higher than TS-total of the controls (28.4 \pm 20.4 compared to $13.9 \pm 10.7$ ). Inhibition of TS catalytic activity after $5 \mathrm{FU}$ or $\mathrm{LV} / 5 \mathrm{FU}$ was observed in 11 out of 15 samples. An elevation of TS-total activity was observed $48 \mathrm{~h}$ after administration. The small number of colon mucosa samples and the large variation allowed no further time-dependent or treatment-related evaluation.

detection limit; these were considered not evaluable. Protein content: $42 \pm 10 \mathrm{mg}$ protein $/ \mathrm{g}$ wet weight. $e / n$ number of available samples compared to the total number of samples. Control values from Peters et al. (1991)

\begin{tabular}{|c|c|c|c|c|c|}
\hline \multicolumn{2}{|l|}{ Time (h) } & Drug & $e / n$ & \multicolumn{2}{|c|}{ Thymidylate synthase (fmol/mg protein) } \\
\hline Control & & - & $7 / 10$ & & $62.7 \pm 31.4$ \\
\hline 24 & 22.75 & $5 \mathrm{FU}$ & $1 / 1$ & 0 & 192.0 \\
\hline 48 & $49.25 ; 67.50$ & $5 \mathrm{FU}$ & $2 / 2$ & $17.8 ; 0$ & $59.0 ; 20.9$ \\
\hline 48 & $43.80-50.30$ & $\mathrm{LV} / 5 \mathrm{FU}^{\mathrm{a}}$ & $5 / 8$ & $20.2 \pm 13.5^{* *}$ & $66.9 \pm 42.6$ \\
\hline
\end{tabular}

${ }^{a}$ Specification LV dose per sample: $500 \mathrm{mg} / \mathrm{m}^{2}$ DL-LV (1); $250 \mathrm{mg} / \mathrm{m}^{2} \mathrm{~L}-\mathrm{LV}(1) ; 25 \mathrm{mg} / \mathrm{m}^{2}$ DL-LV (3) ${ }^{* * *}$ Statistics: TS-free is lower than TS-tot: ${ }^{*} P=0.05 ;{ }^{* *} P=0.02$, paired $t$-test. TS-tot $2 \mathrm{~h}$ after $5 \mathrm{FU}$ is lower than other TS-tot values ${ }^{* * * *} P=0.03$, unpaired $t$-test 


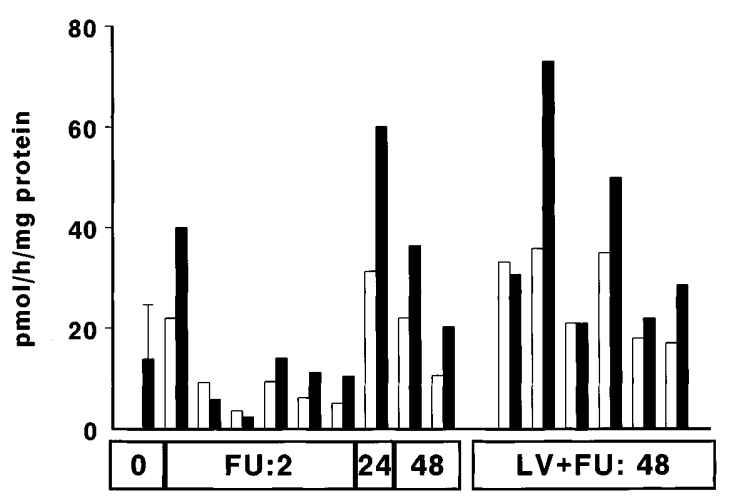

Fig. 3 Inhibition of thymidylate synthase (TS) catalytic activity at $1 \mu \mathrm{M}$ dUMP in human colon mucosa, obtained from patients who received a single dose of $500 \mathrm{mg} / \mathrm{m}^{2} 5$-fluorouracil $(5 F U)$ or $500 \mathrm{mg} /$ $\mathrm{m}^{2}$ leucovorin $(L V)$ and $500 \mathrm{mg} / \mathrm{m}^{2} 5 \mathrm{FU}$. The interval between administration of the drug(s) and surgical removal of the tissue is indicated at the bottom of the figure. White bars TS-residual, black bars the corresponding TS-total from the same patients. No bar means that the activity has been measured, but was below the detection limit of the assay. At 0 h, data from Peters et al. (1991) were used. This bar represents the mean of TS catalytic activity in colon mucosa of 10 untreated patients. Statistics: TS-total activity $48 \mathrm{~h}$ after drug administration is significantly higher than TS activity of the control $(P=0.006$, unpaired $t$-test $)$

\section{Discussion}

TS was inhibited in normal tissues after 5FU administration, but the extent of inhibition varied with the tissue. The most pronounced TS inhibition in mice was observed in the intestinal mucosa, while there was a tendency for higher TS inhibition in human colon tissue than in human liver tissue, when calculated TS-free/TStot values were used as markers for TS inhibition (Tables 4 and 5). A large degree of TS inhibition in bone marrow cells after 5FU administration was observed for mice. This effect appeared to be very similar to that observed for rats (van der Wilt et al. 1995). In murine liver and in about $50 \%$ of the human liver samples, TS inhibition was maintained for $48 \mathrm{~h}$ after 5FU.

When we added LV to the treatment schedule we expected to enhance the 5FU-mediated TS inhibition. This could not be evaluated in murine intestinal mucosa with the TS assays because single-agent 5FU already caused complete inhibition of the enzyme. Inhibition of TS activity in the bone marrow cells after LV/5FU treatment of the mice was not very different from that observed after $5 \mathrm{FU}$ treatment. It was remarkable that, in the livers of these animals, no inhibition of TS was observed after $\mathrm{LV} / 5 \mathrm{FU}$ treatment.

We observed a similar trend in human livers. Samples of patients obtained $48 \mathrm{~h}$ after LV/5FU usually had higher TS-free values (FdUMP binding to TS) than samples obtained $48 \mathrm{~h}$ after 5FU. Concentrations of natural folates measured in the liver were higher than those in other tissues (Steinberg et al. 1979). Furthermore it is likely that mice have even higher folate levels in their liver, because of their folate-rich diet. Conse- quently addition of LV to the 5FU administered is unlikely to increase TS inhibition in normal liver. Differences of TS inhibition in human colon mucosa after $5 \mathrm{FU}$ or $\mathrm{LV} / 5 \mathrm{FU}$ administration could not be evaluated, because of the small number of samples.

The contribution of TS inhibition in normal tissues to 5FU-mediated toxicity is difficult to assess. Generally, a pronounced TS inhibition was observed in those normal tissues that were involved in the dose-limiting toxicity of 5FU administration. Severe inhibition of TS activity was observed in the intestinal mucosa and bone marrow of treated mice. This corresponded to gastrointestinal toxicity, which has been described for i.p. injection of 5FU (Bagrij et al. 1993), and to the myeloid toxicity described by Nadal et al. (1989). Besides the effects on TS, the biochemical effect of 5FU administration on RNA should be taken into consideration, since it has been shown that this may play a role in gastrointestinal toxicity in mice (Houghton et al. 1979). Bagrij et al. (1993) showed that, in mice, uridine could partially reverse gastrointestinal toxicity. It is believed that uridine metabolites compete with FUTP for incorporation into RNA. Myeloid toxicity in mice and man could also be reduced by delayed uridine administration (Peters et al. 1988; van Groeningen et al. 1989, 1993). TS inhibition and FUTP incorporation into RNA occur in both normal and rapidly dividing tissues affected by the toxic side-effects of 5FU. From this study it can not be concluded which contributes most to the toxic side-effects.

TS inhibition in liver tissue seemed to be of minor importance, since 5FU does not cause toxic side-effects in the liver. However, there are some remarkable features of TS inhibition in liver tissue that might explain why no toxic side-effects occur. First, the extent of TS inhibition, evaluated by FdUMP binding assay, was less than in mucosa, for example. Second, TS inhibition was not enhanced by co-administration of $\mathrm{LV}$, indicating that $5,10-\mathrm{CH}_{2}-\mathrm{H}_{4}$-folate was not limiting for TS inhibition in this tissue. Imbalance of the folate homeostasis in the liver, caused by LV administration, induced a reverse effect on TS inhibition. Third, residual TS activity $48 \mathrm{~h}$ after 5FU administration was higher than TS activity in the control liver. A similar increase of TS-total was observed in rat liver after FU administration (van der Wilt et al. 1995).

The increase of TS activity after $48 \mathrm{~h}$ was also observed in human colon mucosa. It appears to be a general mechanism occurring both in vitro and in vivo as a response to $5 \mathrm{FU}$ exposure and was first described by Chu et al. (1991). The elevation of TS activity might be a defence mechanism of cells and tissues against 5FU toxicity.

The decrease in TS activity, observed after the dissociation procedure, was specific for liver tissue. Previous tests in colon tumours from mice and men did not reveal such effects. The presence of many proteases in liver tissue might affect the stability of TS during the incubation for $3 \mathrm{~h}$ at $30^{\circ} \mathrm{C}$. Also the $K_{\mathrm{i}}$ for FdUMP was 
altered, so considerable changes of the protein were induced by this procedure.

Parallel to this study in normal tissues we measured TS inhibition in murine and human colon tumours (van der Wilt et al. 1992; Peters et al. 1994). Although TS levels are higher in tumour tissue, the extent and, what is more important, the retention of the inhibition in normal tissues appeared to be less than in tumours obtained from the same animals or the same patients. This implies that, in tumour tissue, a stronger cytotoxic effect of 5FU, measured by TS inhibition, occurs than in normal tissues. So, despite toxic side-effects, 5FU treatment seems to be selective for tumour tissue. This study shows that, in normal tissues, especially bone marrow and intestinal/ colon mucosa, pronounced 5FU-mediated TS inhibition could be measured. The same tissues are known to be involved in toxic side-effects of 5FU. Toxicity is probably not only caused by 5FU-related effects on RNA but may also be mediated by TS inhibition.

Acknowledgement This study was supported by the Dutch Cancer Society (Koningin Wilhelmina Fonds by grants IKA-VU 88-20; 92-88 and by Wyett-Lederle, the Netherlands). These experiments were partly performed at the KDL (clinical animal laboratory) of the Free University.

\section{References}

Bagrij T, Kralovanski J, Gyergyay F, Kiss E, Peters GJ (1993) Influence of uridine treatment in mice on the protection of gastrointestinal toxicity caused by 5-fluorouracil. Anticancer Res 13:789-794

Chu E, Koeller DM, Casey JL, Drake J, Chabner BA, Elwood PC, Zinn S, Allegra CJ (1991) Autoregulation of human thymidylate synthase messenger RNA translation by thymidylate synthase. Proc Natl Acad Sci USA 88:8977-8981

Danenberg PV (1977) Thymidylate synthetase - a target enzyme in cancer chemotherapy. Biochim Biophys Acta 473:73-92

De Bruijn EA, Remeyer L, Tjaden UR, Erkelens C, De Brauw LM, Van de Velde CJH (1986) Non-linear pharmacokinetics of 5-fluorouracil as described by in vivo behaviour of 5,6-dihydro5-fluorouracil. Biochem Pharmacol 35:2461-2465

Harrison SD Jr, Denine EP, Peckham JC (1978) Qualitative and quantitative toxicity of single and sequential sublethal doses of 5-fluorouracil in $\mathrm{BDF}_{1}$ mice. Cancer Treat Rep 62:533-545

Houghton JA, Houghton PJ, Wooten RS (1979) Mechanism of induction of gastrointestinal toxicity in the mouse by 5-fluorouracil, 5-fluorouridine, and 5-fluoro-2'-deoxyuridine. Cancer Res 39:2406-2413

Leichman CG (1994) Prolonged infusion of fluorinated pyrimidines in gastrointestinal malignancies: a review of recent clinical trials. Cancer Invest 12:166-175

Martin DS, Stolfi RL, Sawyer RC, Young CW (1982) High dose 5-fluorouracil with delayed uridine "rescue" in mice. Cancer Res 42:3964-3970
Nadal JC, Van Groeningen CJ, Pinedo HM, Peters GJ (1988) In vivo potentiation of 5-fluorouracil by leucovorin in murine colon carcinoma. Biomed Pharmacother 42:387-393

Nadal JC, Van Groeningen CJ, Pinedo HM, Peters GJ (1989) Schedule-dependency of in vivo modulation of 5-fluorouracil by leucovorin and uridine in murine colon carcinoma. Invest New Drugs 7:163-172

Nord LD, Stolfi RL, Martin DS (1992) Biochemical modulation of 5 -fluorouracil with leucovorin or delayed uridine rescue. Biochem Pharmacol 43:2543-2549

Peters GJ, Van Groeningen CJ (1991) Clinical relevance of biochemical modulation of 5-fluorouracil. Ann Oncol 2:469480

Peters GJ, Van Dijk J, Nadal JC, Van Groeningen CJ, Lankelma J, Pinedo HM (1987) Diurnal variation in the therapeutic efficacy of 5 fluorouracil against murine colon cancer. In Vivo 1:113118

Peters GJ, Van Dijk J, Laurensse E, Van Groeningen CJ, Leyva A, Nadal JC, Pinedo HM (1988) In vitro biochemical and in vivo biological studies of uridine "rescue" of 5-fluorouracil. Br J Cancer 57:259-265

Peters GJ, Van Groeningen C, Laurensse EJ, Pinedo HM (1991) Thymidylate synthase from untreated human colorectal cancer and colonic mucosa: enzyme activity and inhibition by 5-fluoro2'-deoxyuridine-5'-monophosphate. Eur J Cancer 27:263267

Peters GJ, Lankelma J, Kok RM, Noordhuis P, Van Groeningen CJ, Van der wilt CL, Meyer S, Pinedo HM (1993) Prolonged retention of high concentrations of 5-fluorouracil in human and murine tumors as compared with plasma. Cancer Chemother Pharmacol 31:269-276

Peters GJ, Van der wilt CL, van Groeningen C, Smid K, Meyer S, Pinedo HM (1994) Thymidylate synthase inhibition after administration of 5-fluorouracil with or without leucovorin in colon cancer patients; implications for treatment. J Clin Oncol 12:2035-2042

Piedbois P, Buyse M, Rustum Y, Machover D, Erlichman C, Carlson RW, et al (1992) Modulation of 5-fluorouracil by leucovorin in patients with advanced colorectal cancer evidence in terms of response rate. J Clin Oncol 10:896-903

Steinberg SE, Campell CL, Hillman RS (1979) Kinetics of the normal folate enterohepatic cycle. J Clin Invest 64:83-88

Swain SM, Lippman ME, Egan EF, Drake JC, Steinberg SM, Allegra CJ (1989) Fluorouracil and high dose leucovorin in previously treated patients with metastatic breast cancer. J Clin Oncol 7:890-899

Van Groeningen CJ, Peters GJ, Leyva A, Laurensse EJ, Pinedo HM (1989) Reversal of 5-fluorouracil-induced myelosuppression by prolonged administration of high-dose uridine. J Natl Cancer Inst 81:157-162

Van Groeningen CJ, Peters GJ, Pinedo HM (1993) Reversal of 5-fluorouracil-induced toxicity by oral administration of uridine. Ann Oncol 4:317-320

Van der wilt CL, Pinedo HM, Smid K, Peters GJ (1992) Elevation of thymidylate synthase after 5-fluorouracil in murine tumors is prevented by the addition of folinic acid. Cancer Res 52:49224929

Van der wilt CL, Marinelli A, Pinedo HM, Cloos J, Smid K, Van de Velde CJH, Peters GJ (1995) The effect of different routes of administration of 5-fluorouracil on thymidylate synthase inhibition in the rat. Eur J Cancer 31a:754-760 